\title{
Appreciating Customer Worth in the Indian Market
}

\author{
Satish Kumar
}

\begin{abstract}
Technological intervention in the Indian market has changed the dimensions of customer approach and identities. Specifically the youth and urban women created different dimensions and space for their survival. The changing attitude and consumerism questioned marketers sustainability. This can be appreciated with identifying role and significance of the stakeholders in the consumer market. The current paper identify the significance of important participants and the strategies to handle them effectively. The current paper is also shed some light upon the innovative strategies for the sustainability of the marketers.
\end{abstract}

Keywords--- E Commerce, Social Media, Social Selling.

\section{INTRODUCTION}

A WARENESS level of the Indian consumer has immensely changed due to the economic growth and technological advancement in our country. Today's consumer has information on his fingertips through the internet and/or his mobile. Be it the decision to purchase a new FMCG product, choose a hotel to add to his travel itinerary or a take his family for a casual Sunday lunch at a new restaurant in town, the new Urban consumer surfs the internet for peer reviews before finalizing his choice of a product or service. The Rural counterpart is also not far behind. This changing lifestyle has posed a major challenge before the marketers. Understanding the finer market segments, innovative advertising, competitive pricing, affordable packaging and customer retention are a few of the challenges that the Indian marketer has to face.

Increasing competition among the service providers has led to various challenges for marketers in delivering customer value. In India post liberalization era has been an eye opener for the consumer. The shift from the sellers' market to buyers' market has opened a whole new world of choices for the customer. Be it the manufacturing or the service sector, marketers everywhere is struggling to entice the various segments of consumers to their respective brand. In the last few years China and Korea have come up as global economies for production of low lost goods. This is another factor which has added to the challenge of providing cost effective quality goods and services to the customer. A combination of changing lifestyles, higher disposable income, greater product awareness and affordable pricing has been instrumental in changing the pattern and amount of consumer expenditure leading to a great economic dynamism.

Satish Kumar, Assistant Professor, Department of Commerce, Manipal University, Manipal.

DOI: 10.9756/BIJIEMS.8342

\section{METHODOLOGY}

The research design chosen for this study is descriptive. This research paper focuses on the changes occurred in the Indian consumers' lifestyles and aims at understanding the innovative strategies used by marketers to retain and delight the new Indian consumer. The information in this paper has been assimilated by the use of secondary data.

\section{ChANGING LifEstyles OF THE Indian CONSUMER}

The Indian customer today can be divided into four major segments as discussed in the Spencer Stuart -Three major emerging segments were identified: Kids, the Youth (including the young working singles) and the Urban Indian Woman. These segments have shown a tremendous increase in influencing and driving purchasedecisions and hence are huge drivers of change in the consumer market.More interestingly, purchases are being driven not by necessity, but to satisfy individual needs. There are 300 million children aged between 4-14 years in India - a vast market by any standards. The role that children play in purchase decisions has changed dramatically in the past $4-5$ years.

\section{Youth: Charting Their Own Path}

It is due to the demographic advantage, Indian market is dominated by the youth customers of average 25 years in the category. Most of the consumer goods companies are targeting this large chunk of the segments in the market with attractive incentives and advertisements. These customers tech savvy in their approach. They are much attracted by the new concepts and values along with cultural backup. Life is about visiting religious centres with their parents and then spending theevening with friends at the local club or a similar social venue. The outsourcing phenomenon in India has been the main driver of this consumer segment. A larger number of younger people now have cash in hand and this combined with increasing brand awareness has resulted in a lot of spending on leisure and personal gratification. This has also brought about a dramatic change in the concept of saving. The young generation is also guided with e platforms where there are motivated with cash backs and extended customer services. They look for short term gadgets so that they will get the opportunity change them frequently and experiment them for new updates and technology. Totally youths are in flying colors and speed network. Therefore youth market fast moving and changing segment of the market.

All these kind of fast changing life style of the youths customers raised several questions to marketers that how to handle the frequency of the change and how to keep youth customers busy in the market, so that the visibility and accessibility of the young customers in the market is determined. Secondly changing technology phase and product 
innovation in the market whether will have same speed or if it is lag, then how to bridge the gap?. Therefore marketers has to have alternatives and innovations so that youth customers will be kept active for the products.

\section{The Urban Woman: Redefining Space and Role}

Changing social and economic identity of the women, made active participant in the modern customer world. Added to this, technology and e platforms enabled women to redefine with new space and role in the market. Family and work life balance approach added women into active participant in the Indian market. Being a planner and spending head of the family, enabled her role as a consumer and also saver for the future. Secondly improved quality of life, made her to look for higher market with high standard market for their day to day life. Urbanization process itself improved her status as a customer to the new fast moving market segment. Changing life style and cultural values added her basket go for more choices and brands.

\section{INFLUENCE OF TECHNOLOGY ON THE INDIAN CONSUMER MINDSET}

Internet has become one of man's greatest friends. Search engines like Google and Sulekha.com have made information available on the Indian consumer's fingertips.

Affordability of technology has made it easy for a large percentage of the young population to efficiently use internet for simple transactions like:

- Booking movie tickets, travel, hotel booking etc. Sites like www.tripadvisor.inhelp the tech savvy find out reviews about different hotels before deciding to choose them based on their travel plans and itinerary.

- Payment of telephone, electricity bills, mobile bills, insurance premium payment, DTH recharge. Apart from the simplicity of this invention, it also helps consumer join the 'Green Brigade' and save paper for a cleaner and safer environment.

Ecommerce is also an upcoming trend which the young Indian is using efficiently to get the best deals available in the market. ebay.in, shopping.rediff.com, futurebazaar.com, khoj.com are few popular websites which are being readily used by consumers in India.

Sites like www.compare.comhelp consumers not only compare various products and get the best deals in the market, but also read reviews of products before purchasing them.

Sites like http://www.mobilclub.org/.

http://www.nokia.co.in/services-and-apps/ovi-by-nokia etc are gateways to download music, games, softwares on to a cell phone.

\section{MARKETERS CHALLENGES IN INDIA}

Marketers are finding it challenging to captivate customers for a considerable period of time to gain some substantial profit. Gone are the days when a brand could just hire a celebrity to advertise for a product and expect sales to shoot up. In the current scenario, the consumer stops to look at an advertisement only when it's innovative and interesting. If this happens, a brand has been able to trap customer attention for a few seconds, got him/her thinking about the product/service and maybe think of a probable purchase in future.The rate of technological and innovative changes in the market is so high that brands are coming up with competitive strategies to retain customers. Facebook and Twitter are ways a trendy Indian socialises and discusses on various issues. These are also ways consumers influence each other's decisions to purchase or not any product/service.

Moreover, the Indian customer's mindset has become more practical, intelligent, comparative and realistic. Getting them to purchase a product/service is not as easy as it was before. Marketers are therefore using various methods to grab the Indian consumer's attention. Idea Cellular's (Idea) advertisement (ad) endorsed by the Indian film star Abhishek Bachchan (Bachchan) won the 'Best celebrity endorsement award' at NDTV Tech Life Awards. The IDEA campaign carries a socially relevant message in today's commercial environment and the brilliant concept of encouraging two-way communication between the government and people has connected with millions across India." "Companies that have understood the nuances of handling India's complex business environment have been successful. For instance, auto giant Hyundai was sensitive about the fact that Indian consumers attached a lot of importance to lifetime ownership costs while purchasing a car. It thus kept the fuel efficiency high, priced spare parts reasonably and incorporated other changes to suit Indian consumers. As a result Hyundai has emerged as a leading player in India's small car market. LG is another successful foreign player in India. It invested in feeling the pulse of the Indian consumers. For instance, it introduced a $6 \mathrm{~kg}$ washing machine instead of its $4.5 \mathrm{~kg}$ model, keeping in mind the need of a large Indian household. Thus, market intelligence (MI) is very important for understanding the Indian business environment.”

\section{ShIFT From SELLERS MARKET TO BUyers MARKET}

While consumers across the world are seeing a growing number of "Made in India" labels on the goods they buy, Indian shoppers are witnessing a more subtle change. Increasingly, multinational companies are selling products that are not just made in India but that are made for India.

"The willingness of big brands to customize their products was never the issue," says Harminder Sahni, managing director of Technopak Advisors India, one of the country's largest management consultancies. "What has changed is that the Indian market has finally reached a critical mass -- after the U.S. and China, this is the largest consumer market in the world -- that justifies the investment."

Increasing competition, technological advancement has spoilt the Indian consumer today with a variety of options laid down in a platter for him/her. Therefore, today customer service is just not enough and organisations are increasing aiming at delighting them. One little known concept in this field is the concept of Moment of Truth.

Jan Carlzon, the former president of Scandinavian Airlines has defined MOT as: 
"Any time a customer comes into contact with any aspect of your business, however remote, that customer has an opportunity to form an impression.”

Every service organization routinely experiences opportunities to personally interact with their customers through their frontline employees. During these interactions, the customer is mentally evaluating the service they are experiencing and forming a lasting opinion about your organization.

These notable interactions have been labelled the "moment of truth" by Richard Norman in his book Service Management, a term that implies the critical role they can play in the success of your company. High performance organizations have trained their frontline employees not only to recognize these moments of truth, but to also use them to positively influence their customers.

\section{HAPPy Customers BRing More Customers}

Every business should be based on long term relationships with customers. Normally $80 \%$ of revenue is generated by $20 \%$ of valuable and satisfied customers. Paying off for high quality service and deems relationship with manufacturer, the customers act as brand ambassadors and refer other customers to buy. The process of retaining customers like this will help the organization to gain more profit. Due to enhanced profit the capital could be shared with acquisition cost of customers by utilizing it more on advertising and campaigning events to attract more new customers.

(www.managementstudyguide.com)

\section{E-REVIEWS - THE NEW WORLD OF ADVERTISEMENT}

One of the strong customer identity about the product and its services are $\mathrm{E}$ reviews. Most of the customers and especially youths follows $\mathrm{E}$ reviews as a strong instrument for assessing the product in the market. Therefore most of the companies only promotes reviews and grades for their own products and tries to encourage through incentives for the review. Even negative reviews are very much usefull for the companies to improve the quality of their product without much cost. Therefore it is important to identify the right review and customer will also rightly guided by the reviews. It is observed that personal bias and individuality affects the reviews.

\section{CONCLUSION}

In total we can summarize that, each segment of the market has its own identity and features. Therefore it is required to recognize the appropriate change and change accordingly to the needs of the customer to improve the sale and customer satisfaction. Secondly this will enhance the base of the customers and space for the innovations and profitability of the firm. Thirdly happy customers carry right brand image and enhanced sales for the companies which in turn improve the productivity and GDP of the country.
[2] Brand Awareness and Preference in Rural Markets (2008) - By . Sanjay Patro (Professor XLRI) and Dr. Sanjeev Varshney (Assistant Professors XLRI). http://dspace.iimk.ac.in/bitstream/2259/458/1/RM168.pdf.

[3] Marketing Trends and Challenges in Year 2010 - By Tharmakulasingam Ragulan -http://ezinearticles.com/?Marketing-Trends-and-Challengesin-Year-2010\&id=3432922.

[4] http://www.slideshare.net/mybagga/pantaloons.

\section{REFERENCES}

[1] http://debiprasad.net/i-love-my-india/brand-awareness-and-india. 